Int. J. Dev. Biol. 48: 319-326 (2004)

Original Article

\title{
Acceleration of early chick embryo morphogenesis by insulin is associated with altered expression of embryonic genes
}

\author{
VIDYA PATWARDHAN, MADHAVI GOKHALE and SURENDRA GHASKADBI* \\ Division of Animal Sciences, Agharkar Research Institute, Pune, India
}

\begin{abstract}
In the present study, we show that insulin accelerates early morphogenesis in gastrulating chick embryo explants cultured in vitro, whereas antiserum to insulin adversely affects this process. Comparison between length of body axis of control and treated embryos clearly brings out the significant acceleration of development by excess insulin (0.175 to $17.5 \mathrm{nM})$. In embryos treated with 87.5 and $175 \mathrm{nM}$ insulin, a high occurrence of abnormalities is observed. Treatment of embryos with antiserum to porcine insulin results in a high percentage of abnormalities, particularly in the forming neural tube. In situ hybridization of whole embryos using digoxigenin-labeled riboprobes showed that insulin modifies the expression of crucial developmental genes within 2 hours. While Brachyury, a pan-mesodermal marker gene, ERNI, the earliest known marker for neural induction in chick, and noggin, important in neural tube patterning, are upregulated, expression of goosecoid, necessary for gastrulation movements, does not appear to be significantly altered. During the same time, insulin does not exert any mitogenic effect on chick embryonic cells as assessed by nuclear counts. These findings demonstrate that insulin plays an important role in the early morphogenesis of the chick embryo. The function of insulin appears to be mediated by specific genes which orchestrate pattern formation during early development.
\end{abstract}

KEY WORDS: insulin, chick embryo, early development, accelerated morphogenesis, developmental gene expression

\section{Introduction}

Recent studies from our laboratory show that several molecules performing important functions in the adult life of an organism also participate in crucial phenomena in early development (Khot and Ghaskadbi, 2001; Patwardhan and Ghaskadbi, 2001; Karandikar and Ghaskadbi, 2003). Insulin and related ligands is one group of molecules important in early embryonic development especially of the nervous system (De Pablo et al., 1990; De Pablo and Roth, 1990; Ghaskadbi and Ghate, 1993, 1995; De Pablo and De La Rosa, 1995). We have shown that insulin plays an essential role in prepancreatic development of the frog Microhyla ornata (Ghaskadbi and Ghate, 1993). Insulinrelated molecules probably participate in the induction and/or pattern formation of the nervous system (Ghaskadbi and Ghate, 1995) by recruiting specific genes (Chatterjee and Ghaskadbi, 2002).

Insulin (De Pablo etal., 1982) and receptors for insulin (Bassas et al., 1987; Girbau et al., 1989, 1992) have been shown to be present in developing chick embryo. Earlier studies on growth promoting effect of insulin and growth retarding effect of antise- rum to insulin (De Pablo etal., 1985; Girbau etal., 1987), however, have concentrated on late embryonic (post-neurula) development of the chick embryo. Since our studies with frog embryos strongly suggest that insulin is important for crucial developmental events much before neurulation, we have examined the role of insulin during early critical events such as mesoderm induction and neurulation (neural tube formation) in chick embryo. A number of genes that regulate early development and differentiation are those involved in mesoderm and neural induction. We have studied the influence of insulin on the expression of selected marker genes essential for each of these processes. We have simultaneously studied effects of insulin on cell numbers to see if modulation of embryonic gene expression is accompanied by mitogenic effect of insulin.

Expression of Brachyury is one of the first and the most important response to inductive interactions that lead to mesoderm formation in a vertebrate embryo (Smith, 2001). In chick embryo,

Abbreviations used in this paper: BCIP, 5-bromo 4-chloro 3-indolyl phosphate; Dig, digoxigenin; ERNI, Early Response to Neural Induction; HH, Hamburger Hamilton; NBT, 4-nitroblue tetrazolium; PC, Pannet Compton.

\footnotetext{
*Address correspondence to: Dr. Surendra Ghaskadbi. Division of Animal Sciences, Agharkar Research Institute, G.G. Agarkar Road, Pune 411 004, India. Fax: +91-20-2565-1542. e-mail: ghaskadbi@vsnl.net
} 
Brachyury (c-bra) is differentially expressed in cells located in the primitive streak. Those which express the maximum amount of Brachyury protein, predominantly form mesoderm (Wilson and Beddington, 1997). Since anti insulin antiserum treatment led to severe neural abnormalities and insulin enhanced the neural tube differentiation, we chose two markers involved in neural induction and differentiation. ERNI (Early Response to Neural Induction) is the earliest known marker for neural induction in chick (Streit et al., 2000). It begins to be expressed even before primitive streak formation in the prospective neural precursors and at gastrulation stage, it marks the limits of prospective neural plate (Streit et al., 2000). Nogginis a neural inducer in amphibian embryo (Smith and Harland, 1992) while in chick, it is important in neural tube patterning but does not show the ability to induce neural tissue (Connolly etal., 1997; Streit and Stern, 1999). Goosecoid, a homeobox gene, is necessary for gastrulation movements (Cho et al., 1991). It is expressed in the organizer region during gastrulation in Xenopus (Blumberg et al., 1991) and around Hensen's node in chick (Izpisüa-Belmonte et al., 1993). Ectopic expression of goosecoid leads to the recruitment of neighboring cells into forming a secondary axis in Xenopus (Niehrs et al., 1993) and in chick (IzpisüaBelmonte etal., 1993). The product of goosecoid, a homeodomaincontaining protein, is a transcription factor that regulates the expression of a number of downstream genes (Izpisüa-Belmonte et al., 1993). Expression of these downstream genes is essential for the progression of gastrulation leading to the formation of the three basic germ layers, ectoderm, mesoderm and endoderm.

Results of the present study show that exogenous insulin enhances overall growth and differentiation in early chick embryo. Deprivation of endogenous insulin causes abnormalities in development especially of the neural structures. Insulin appears to bring about its effects by altering the expression of Brachyury, ERN/ and noggin. The pattern of goosecoid expression, on the other hand, does not appear to be significantly affected. Further, modulation of embryonic gene expression by insulin is brought about independent of the mitogenic effects of insulin indicating that insulin acts as a differentiation factor in this system.

\section{Results}

\section{Effects of exogenous insulin at gross morphological level}

Effects of insulin on the early development of chick embryo explants cultured in vitrowere assessed at five different concentrations. At concentrations lower than $0.175 \mathrm{nM}$, insulin did not have any detectable effect on embryonic development. The development was influenced by insulin at all concentrations between $0.175 \mathrm{nM}$ and $175 \mathrm{nM}$ (Table 1). Insulin brought about stimulation of development at all the five concentrations. The three lower concentrations $(0.175,1.75$ and $17.5 \mathrm{nM})$ were more effective in this respect (Table 1). The proportion of embryos showing stimulated growth accompanied by completely normal development (stimulated normal embryos) was also maximal at these three concentrations. Insulin at the two higher concentrations used ( 87.5 and $175 \mathrm{nM}$ ) also brought about stimulation of development in more than half the treated embryos. However, the proportion of abnormal and dead embryos also increased at these concentrations. Insulin thus exhibited maximal beneficial effect up to $17.5 \mathrm{nM}$. This concentration was used for assessing the influence of insulin on embryonic gene expression.
At the end of the treatment (about $38 \mathrm{~h}$ post-laying: $\mathrm{HH}$ stage 10-11), normal control embryos exhibited well developed brain, notochord, heart, somites, etc. (Fig. 1A). The stimulated normal embryos exhibited an overall stimulated development (Fig. 1B). Some of the indicators of stimulation of development included increased number of somites, larger head region and/ or betterdeveloped heart. Some of them exhibited enlargement of all embryonic structures along with increase in the length of the body axis (see later). Some of the stimulated abnormal embryos possessed abnormalities such as somites placed abnormally close to one another, occurrence of unpaired somites, partial inhibition of neural tube closure and retardation in the compart-

TABLE 1

\section{STIMULATION OF DEVELOPMENT IN CHICK EMBRYO EXPLANTS CULTURED IN VITRO IN PRESENCE OF EXCESS INSULIN*}

\begin{tabular}{lllllll}
$\begin{array}{l}\text { Dose of } \\
\text { Insulin }(\mathrm{nM})\end{array}$ & $\begin{array}{l}\text { Total } \\
\text { embryos }\end{array}$ & $\begin{array}{l}\text { Normal } \\
\text { embryos }\end{array}$ & $\begin{array}{l}\text { Stimulated } \\
\text { normal } \\
\text { embryos }\end{array}$ & $\begin{array}{l}\text { Stimulated } \\
\text { abnormal } \\
\text { embryos }\end{array}$ & $\begin{array}{l}\text { Total } \\
\text { stimulated } \\
\text { embryos }\end{array}$ & $\begin{array}{l}\text { Abnormal } \\
\text { or dead } \\
\text { embryos }\end{array}$ \\
\hline 0 & 107 & $85(79.44)$ & - & - & - & $22(20.56)$ \\
0.175 & 11 & - & $6(54.54)$ & $2(18.18)$ & $8(72.72)$ & $3(27.27)$ \\
1.75 & 33 & $2(6.06)$ & $21(63.63)$ & $4(12.12)$ & $25(75.75)$ & $6(18.18)$ \\
17.5 & 38 & $11(28.95)$ & $15(39.47)$ & $6(15.79)$ & $21(55.26)$ & $6(15.79)$ \\
87.5 & 17 & $2(11.76)$ & $4(23.53)$ & $5(29.41)$ & $9(52.94)$ & $6(35.29)$ \\
175 & 12 & $1(8.33)$ & $6(50.00)$ & $1(8.33)$ & $7(58.33)$ & $4(33.33)$ \\
\hline
\end{tabular}

"Percentages in parentheses.

TABLE 2

\section{EFFECT OF ANTISERUM TO INSULIN ON THE DEVELOPMENT OF CHICK EMBRYO EXPLANTS CULTURED IN VITRO}

\begin{tabular}{llcc} 
Treatment & $\begin{array}{l}\text { Total } \\
\text { embryos used }\end{array}$ & $\begin{array}{l}\text { Normal } \\
\text { embryos }\end{array}$ & $\begin{array}{l}\text { Abnormal } \\
\text { embryos }\end{array}$ \\
\hline P.C. saline & 45 & $40(88.88)$ & $5(11.11)$ \\
Preimmune rabbit IgG (1:5000) & 21 & $15(71.43)$ & $6(28.57)$ \\
Antiserum to insulin (1:5000) & 22 & $12(54.55)$ & $10(45.45)$ \\
\hline
\end{tabular}

"Percentages in parentheses.

mentalization of brain. As mentioned earlier (Table 1), insulin brought about abnormal development in some of the treated embryos (Fig. 1 C,D).

Stimulatory effect of insulin on chick embryo development was quantified by measuring the anteroposterior length of the body axis of control and treated embryos (Ghaskadbi et al., 1994). The measurements (Fig. 1E) showed that treatment with all five concentrations of insulin resulted in stimulation of development. Here again insulin was most effective in the concentration range of 0.175 to $17.5 \mathrm{nM}$ and could stimulate development to the extent of 14 to $21 \%$ over the control embryos. Marginal stimulation was recorded at $175 \mathrm{nM}$ insulin but this was not statistically significant (Fig. 1E).

\section{Effects of antiserum to insulin}

Treatment of chick embryos with antiserum to insulin (1:5000) resulted in abnormal development in $45 \%$ of treated embryos (Table 2). In comparison, controls treated with comparable dilution of rabbit serum exhibited normal development in more than $70 \%$ cases. Amongst PC saline controls, about $90 \%$ showed normal development (Table 2). Abnormalities induced due to 

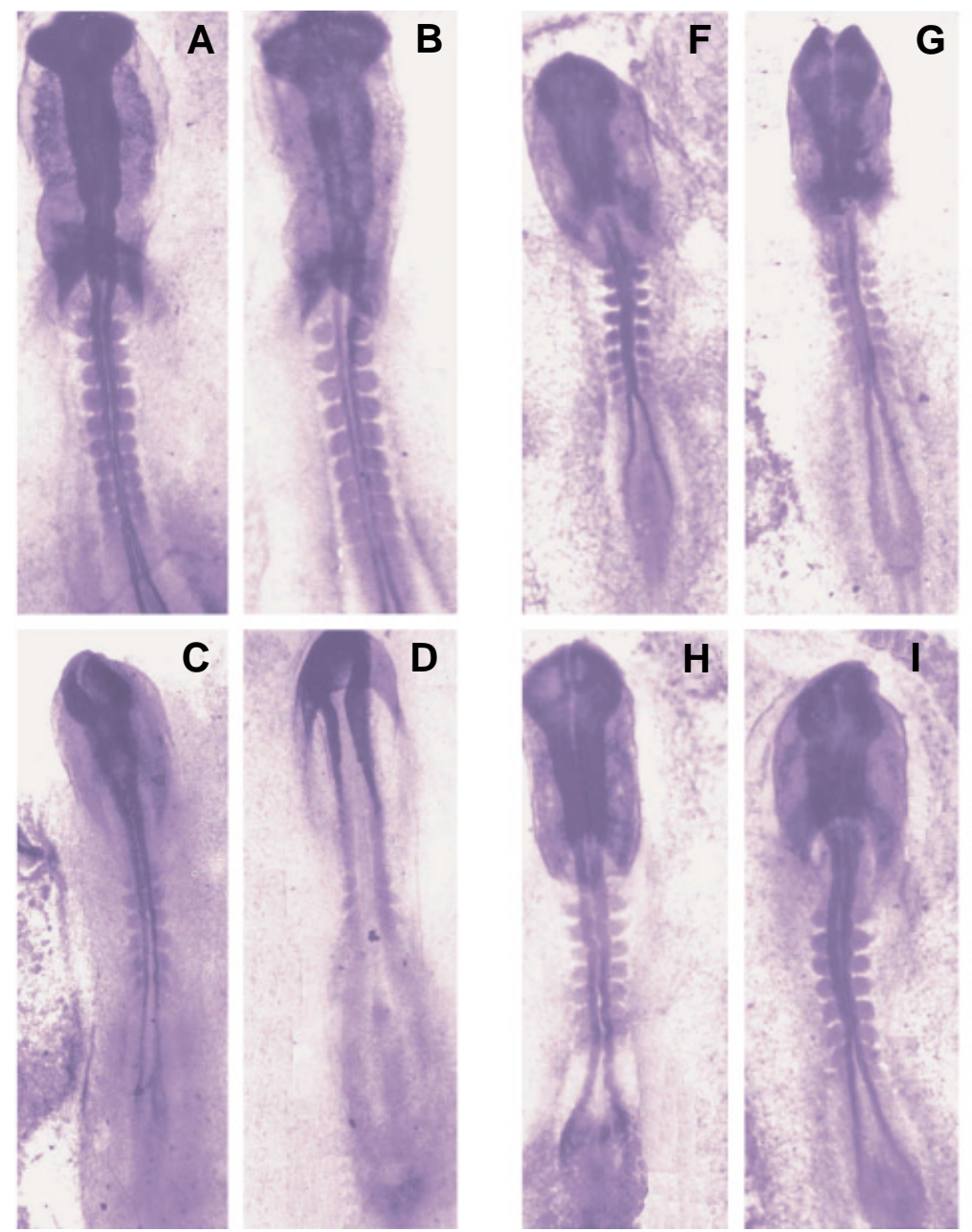
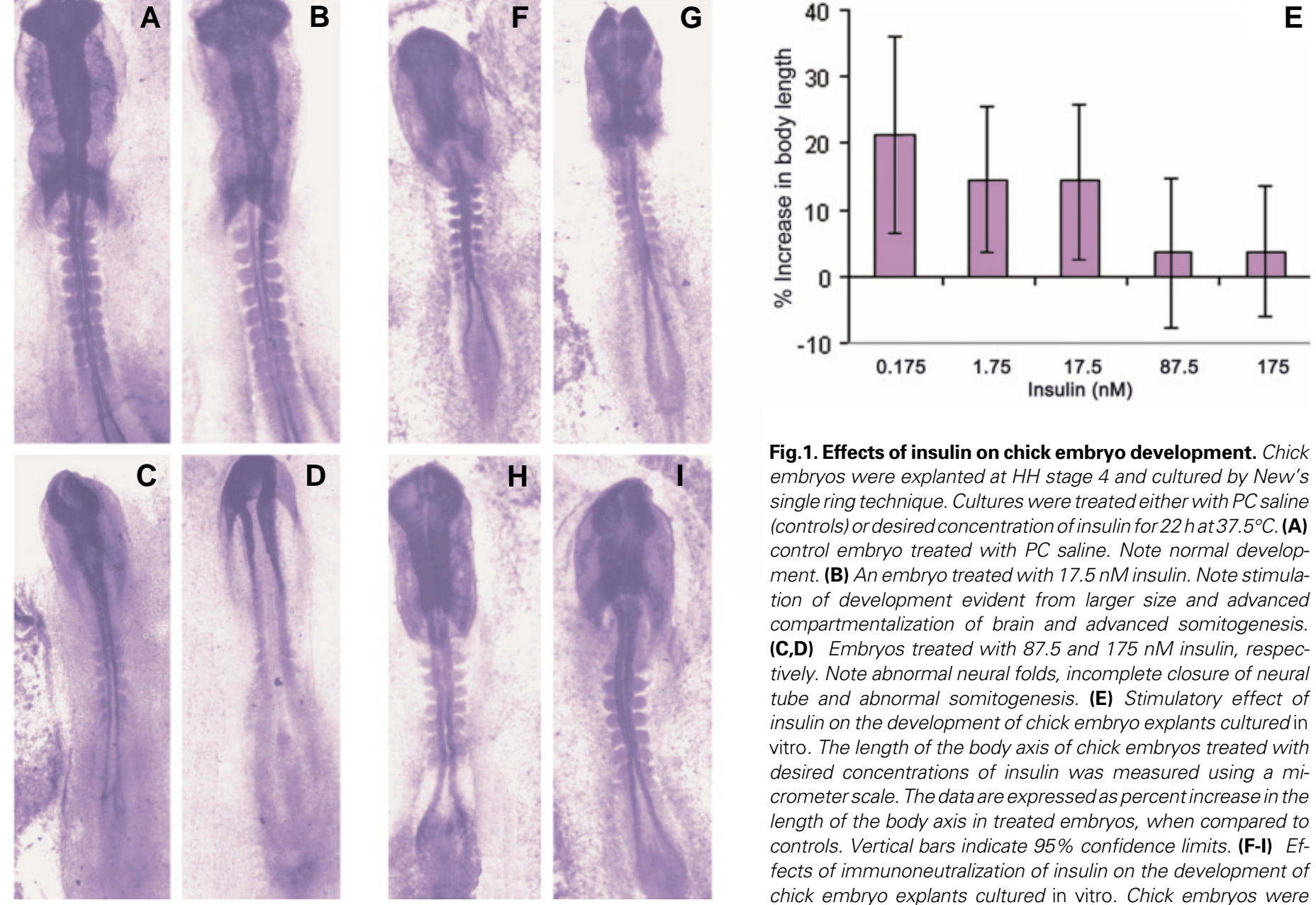

Fig.1. Effects of insulin on chick embryo development. Chick embryos were explanted at HH stage 4 and cultured by New's single ring technique. Cultures were treated either with $P C$ saline (controls) or desired concentration of insulin for 22 hat $37.5^{\circ} \mathrm{C}$. (A) control embryo treated with PC saline. Note normal development. (B) An embryo treated with $17.5 \mathrm{nM}$ insulin. Note stimulation of development evident from larger size and advanced compartmentalization of brain and advanced somitogenesis. (C,D) Embryos treated with 87.5 and $175 \mathrm{nM}$ insulin, respectively. Note abnormal neural folds, incomplete closure of neural tube and abnormal somitogenesis. (E) Stimulatory effect of insulin on the development of chick embryo explants cultured in vitro. The length of the body axis of chick embryos treated with desired concentrations of insulin was measured using a micrometer scale. The data are expressed as percent increase in the length of the body axis in treated embryos, when compared to controls. Vertical bars indicate 95\% confidence limits. (F-I) Effects of immunoneutralization of insulin on the development of chick embryo explants cultured in vitro. Chick embryos were explanted at $\mathrm{HH}$ stage 4 and cultured either in presence of preimmune rabbit serum (control) or antiserum to porcine insulin (1:5000) for $22 \mathrm{~h}$ at $37.5^{\circ} \mathrm{C}$. (F) Control embryo. Note normal development. (G,H,I) Embryos treated with antiserum to insulin. Note various abnormalities in the neural folds, such as, incomplete fusion (H), excessive thickening (H) and wavy appearance (I).

scarcity of insulin, experimentally created by treatment with antiserum to insulin, were mostly in the region of anterior neural tube (Fig. $1 \mathrm{~F}-\mathrm{I})$. These were in the form of either non-fused (Fig. $1 \mathrm{G}$ ), thickened (Fig. 1G) or wavy (Fig. 1I) neural folds. Control embryos treated with preimmune rabbit serum exhibited normal pattern of development (Fig. 1F). A few embryos treated with antiserum to insulin also showed reduced intersomitic gaps (not shown).

\section{Effects of insulin on Brachyury expression}

Expression of Brachyurycould be detected by in situhybridization using DIG-labeled chick Brachyuryprobe. In control embryos developing in PC saline, Brachyury expression was sharply localized around the primitive streak. All the cells about to invaginate through the streak and form various mesodermal derivatives eventually expressed Brachyury(Fig. 2A). Embryos treated with $17.5 \mathrm{nM}$ insulin exhibited expression of the gene in a considerably larger area. In addition to the cells expressing Brachyuryin control embryos, a significantly larger population of cells was made to express the gene after insulin treatment. These cells are present all around the primitive streak (Fig. 2B). As compared to control specimens, insulin treated embryos showed an appreciable enhancement in the intensity also.

\section{Effects of insulin on ERNI expression}

$\mathrm{HH}$ stage 4 control embryos growing in $\mathrm{PC}$ saline showed the expression of $E R N /$ in the prospective neural plate cells present in the area surrounding Hensen's node (Fig. $2 \mathrm{C}$ ). The node itself was also positive for ERNI. Primitive streak was very faintly stained, if at all. The rest of the area pellucida was almost devoid of positive signal. In embryos treated with $17.5 \mathrm{nM}$ insulin for $2 \mathrm{~h}$, the intensity of staining had significantly enhanced while the pattern of staining was comparable to that of control embryos (Fig. 2D). A few embryos, which were at $\mathrm{HH}$ stage 4 at the onset of the treatment, attained stage $4+$ at the end of $2 \mathrm{~h}$ of treatment period. In such cases, control embryos showed stronger staining in the prospective neural plate cells and nascent head process as compared to those remained at stage 4 (Fig. 2E). In insulin treated embryos among these advanced group, enhancement of ERN/ expression was even more dramatic as compared to treated embryos still at stage 4 (Fig. 2F). Not only the intensity of staining had enhanced, but also the horseshoe shaped ERN/positive area 

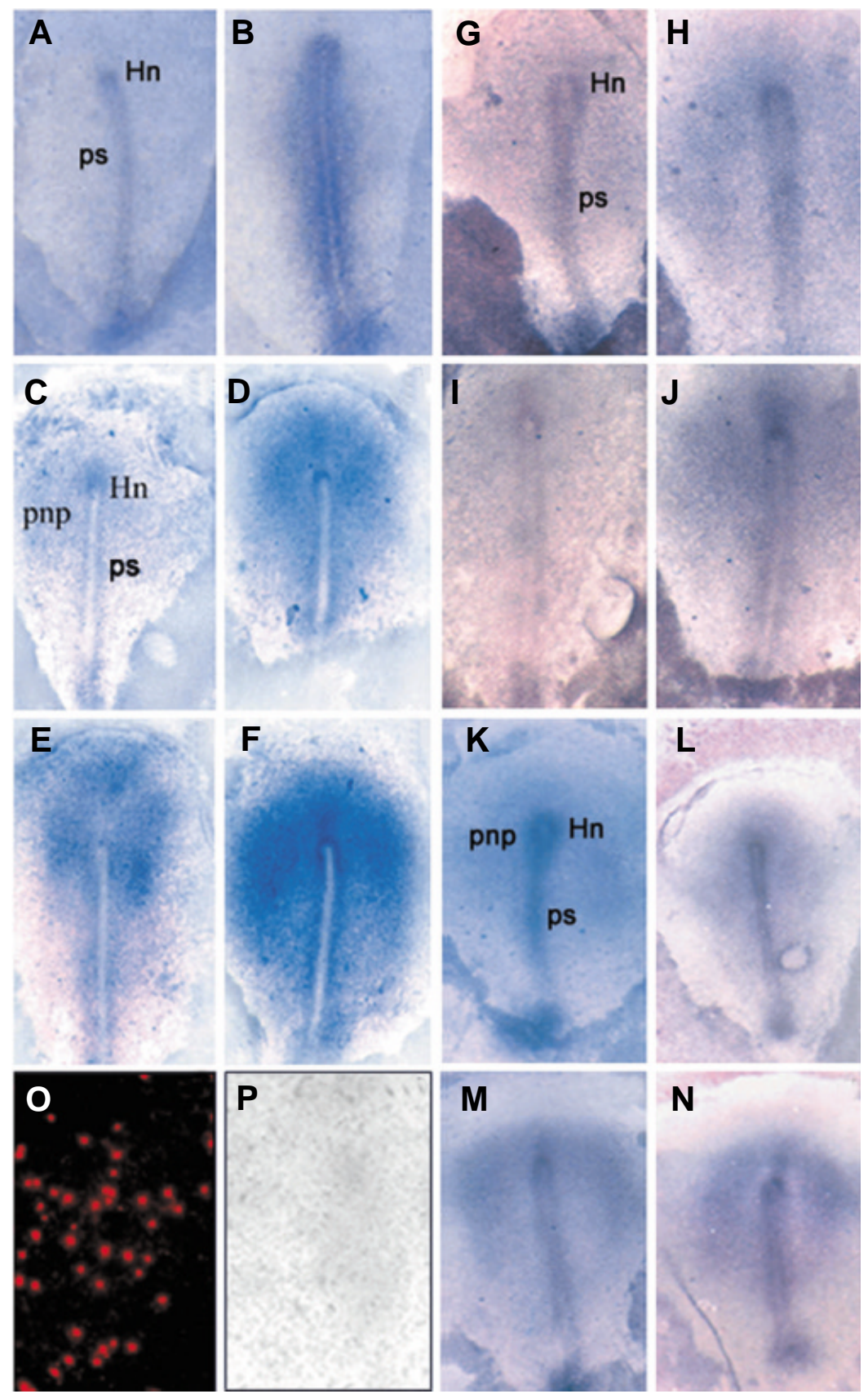

around Hensen's node had laterally expanded across the width of the area pellucida.

\section{Effects of insulin on Noggin expression}

In gastrulating, stage 4 control embryos, cells comprising the Hensen's node express the maximum amount of noggin transcripts, followed by cells of the primitive streak (Fig. 2G). The rest of the area pellucida is faintly stained for noggin RNA. In stage 4 embryos treated with $17.5 \mathrm{nM}$ insulin for $2 \mathrm{~h}$, there is a significant upregulation of noggin transcription especially in the Hensen's node and along the primitive streak (Fig. 2H). Rest of the area pellucida shows no significant change in staining pattern or intensity. In embryos, which reached stage 4+ during treatment duration, staining was darkest in the horseshoe shaped neural plate and the newly laid head process and the fan shaped area along with it (Fig. 2l). Anterior tip of the Hensen's node too was darkly stained. In insulin treated embryos now at stage $4+$, staining intensity was highly enhanced while the pattern remained essentially the same as in controls (Fig. 2J) and in a few cases cells immediately lateral to primitive streak, showed de novo expression of noggin within 2 hours of insulin treatment (not shown).

\section{Effects of insulin on Goosecoid expression}

Goosecoidwas expressed in the cells of the Hensen's node in stage 4 control embryos (Fig. $2 \mathrm{~K}$ ) and to some extent in the primitive streak. Rest of the area pellucida was devoid of staining. Variation in the staining intensity and pattern among stage matched control embryos was the maximum for $c G s c$ probe. As compared to control, majority of the $17.5 \mathrm{nM}$ insulin treated embryos at stage 4 showed no significant change in the intensity or pattern of staining (Fig. 2L). In a few treated embryos especially those which have developed beyond stage 4 , there was a slight enhancement of staining (Fig. $2 \mathrm{~N}$ ) as compared to stage matched controls (Fig. 2M).

\section{Effects of insulin on cell number}

The average number of cells per blastoderm in controls was $4.516 \pm 0.75 \times 10^{5}$ while that in insulintreated blastoderm was $4.198 \pm 0.68 \times 10^{5}$. Thus, there

Fig. 2. Effects of exogenous insulin on expression pattern of selected embryonic genes. (A,B) Modulation of Brachyury expression by insulin. Chick embryos were explanted at HH stage 4 and cultured in presence of either PC saline or $17.5 \mathrm{nM}$ insulin for $2 \mathrm{~h}$. Brachyury expression was detected by whole mount in situ hybridization using DIG-labeled probes. (A) Control embryo with norma/Brachyury expression along the primitive streak. (B) Embryo developing in excess insulin showing a considerably larger population of cells along the primitive streak expressing Brachyury. (C-F) Enhancement of ERNI expression due to exogenous insulin treatment. (C) Control embryos at stage 4. Note the expression of ERNI around Hensen's node that is clearly enhanced in insulin treated embryo (D). Enhancement is also distinctly seen in prospective neural area. (E) Expression of ERNI in control embryos at stage 4+. Enhancement of expression is far more clear at this stage (F) in both prospective neural cells as well as in Hensen's node. (G-I) Effects of exogenous insulin treatment onc-Nog expression (G). Noggin in control embryos at stage 4 is expressed in cells of Hensen's node and prospective neural cells. In insulin treated embryos (H) the pattern of noggin expression remained the same as in control embryos while there was an obvious enhancement in the intensity of the staining. (I) Expression ofnoggin in control embryos at stage 4+. The newly laid head process was positive fornoggin. Insulin treatment led to enhancement of noggin expression in prospective neural cells as well as in cells constituting the nascent head process ( $\mathbf{J})$. (K-N) Exogenous insulin treatment does not affect the pattern or level of cGsc expression. In both control embryos at stage 4 (K), as well as in stage matched insulin treated embryos (L), cGsc is expressed in cells of Hensen's node in similar pattern and intensity. In the case of embryos at stage $4+$ too, both control (M) and insulin treated (N) embryos show expression of cGsc in cells of Hensen's node and forming head process in comparable pattern and intensity. (0) Nuclei in Neubauer's chamber under fluorescent microscope after incubating with ethidium bromide. Only nuclei fluoresce, which makes it easy to count accurately. (P) Same field of view under phase contrast microscope. Note that nuclei and yolk granules look similar and are difficult to distinguish from each other. 
was no significant difference between total cells in control and 17.5 $\mathrm{nM}$ insulin-treated embryos over a $2 \mathrm{~h}$ period. Insulin did not exert any detectable mitogenic effect during a period of $2 \mathrm{~h}$ that was used to assess modulation of gene expression by insulin.

\section{Discussion}

Results obtained in the present study demonstrate the ability of exogenous bovine insulin and antiserum to porcine insulin to influence early morphogenesis of pre-neurula chick embryos. Presence of excess insulin at lower concentrations (upto $17.5 \mathrm{nM}$ ) is development promoting while higher concentrations (87.5 and $175 \mathrm{nM}$ ) tend to induce abnormal development. These observations agree with our studies in frog embryos (Ghaskadbi and Ghate 1993, 1995; Ghaskadbi 1998). In older, post-neurula embryos of chick insulin promotes growth at lower concentrations and brings about teratogenic effects at high concentrations (De Pablo et al., 1985). While low concentrations of insulin $(0.1-1.0 \mathrm{ng} / \mathrm{ml})$ increase glucose consumption in explanted chick embryo gastrula by $50 \%$ (Baroffio et al., 1986), at 10-100 ng/embryo, insulin increases the total content of proteins, DNA, RNA, several lipids and enzymes in chick embryos (Girbau et al., 1987). In the present study, stimulation of development by insulin was directly measured as increased anteroposterior axial length of embryos treated at pre-neurula stages. Treatment of gastrulating chick embryos with antiserum to insulin led to abnormal development indicating that even during gastrulation insulin is essential for normal development.

Neurulation (neural tube formation) proceeds from the anterior to the posterior end in the chick embryo. By 24 hours after egg laying ( $\mathrm{HH}$ stage between 4 and 6), the anterior-most (cephalic) parts of the developing embryo almost complete neurulation while the posterior (caudal) parts are still undergoing gastrulation (Gilbert, 2003). Previous studies to assess the role of insulin in chick embryonic development (De Pablo etal., 1985; Girbau etal., 1987) have been carried out on older (day 2-5) embryos in which the general body plan is already established. Present study was designed to specifically assess the role of insulin in younger stages of chick embryo, as this information is not available (Pérez-Villamil et al., 1994). Here we show, using in situ hybridization, that the effects of insulin treatment are at least initiated, if not exerted, before neurulation. In addition, since we observed stimulation of neural tube closure in amphibian embryos after insulin treatment (Ghaskadbi and Ghate, 1993), we had reason to suspect a similar role of insulin in the chick embryo. Results of the present study support our contention that in the chick embryo insulin is important in very early, pre-neurula development when the nervous system is just beginning to form.

More interestingly, insulin possibly influences the spatiotemporal expression pattern of development-specific genes. Since insulin treatment was given at $\mathrm{HH}$ Stage 4 , a stage where gastrulation is at its peak and neurulation is just being manifested, we have selected a set of genes which play important role in these processes.

Brachyury, which belongs to the family of T-box genes (Herrmann et al., 1990), is a pan-mesodermal marker whose expression pattern is highly conserved in vertebrates (Smith etal., 1991; Smith 1997). We studied the influence of insulin on Brachyuryexpression since it is one of the earliest genes expressed after embryonic inductive interactions (Smith et al., 1991; Gilbert, 2003). The pattern of Brachyuryexpression obtained by us in control embryos is comparable to the pattern reported earlier (Kispert et al., 1995). In embryos developing in excess insulin, on the other hand, a clearly modified spatial expression pattern as well as a very significant upregulation of Brachyury was noticed. The treatment resulted in the recruitment of several additional cells to express the gene. The results are especially interesting since the product of Brachyuryis a transcription factor (Kispert et al., 1995). Initiation of Brachyury expression could directly result in the interaction of its product with downstream genes in these newly recruited Brachyury expressing cells. It is tempting to speculate that changes at the transcriptional level could account for the stimulation of development in the following possible manner. Additional Brachyuryexpressing cells mean more mesoderm that, in principle, could induce more ectodermal cells to take the neural fate. Since Brachyuryis required for convergent extension during gastrulation, cell survival and mesoderm formation (Conlon and Smith, 1999), these growth-promoting processes could be enhanced when extra Brachyury is available. Interestingly, chick embryos treated with exogenous FGF at $\mathrm{HH}$ stage 4 show a significant reduction in the length of body axis and corresponding downregulation of Brachyury expression (Khot and Ghaskadbi, 2001) while Bmicroseminoprotein has an exactly opposite effect (Karandikar and Ghaskadbi, 2003) indicating a direct correlation between the two. The response of frog Brachyury to insulin is different however, it is found to be down regulated (Chatterjee and Ghaskadbi, 2002)

$E R N I$, a molecular marker for a very early response to neural inducing signals was recently discovered in avian embryos (Streit et al., 2000) and there is scarcely any report yet on its further characterization or mode of action. It was first detected in pre primitive streak embryos expressed in cells that will contribute to nervous system and later its expression became confined to the border of neural plate till its complete disappearance by early somite stages concurrent to the loss of neural inducing ability of the Hensen's node (Streit et al., 2000). Enhancement of ERN/ expression could be one of the basic mechanisms of promotion of neural differentiation by exogenous insulin. In doing so, effects of insulin would be carried forward in terms of recruiting more cells to express neural specific markers like noggin, ultimately leading to enhanced neural differentiation. In frog, however, like Brachyury, noggin too is down regulated (Chatterjee and Ghaskadbi, 2002).

Noggin codes for a secreted molecule which, in amphibians, acts as a neural inducer by sequestering BMP4, thus allowing the default neural pathway to be selected by the competent cells (Piccolo et al., 1996; Zimmerman et al., 1996). In chick, noggin is expressed in the Hensen's node and neural plate during axial development (Connolly et al., 1997) and later in the neural folds and somites (Hirsinger et al., 1997). Noggin protein does not induce neural tissue in chick but participates in the patterning of the neural tube (Connolly etal., 1997). Chick embryos treated with exogenous FGF during gastrulation develop neural abnormalities and show a significant enhancement in noggin expression (Khot and Ghaskadbi, 2001). Alteration in noggin expression could be one of the causes of the neural abnormalities seen in some of the insulin treated embryos as is the case in FGF treated embryos. In any case, again, the present results demonstrate that insulin is capable of modulating the expression of a gene that is crucial for the patterning of the neural tube. 
Effect of exogenous insulin on goosecoidexpression is equivocal with a majority of stage 4 embryos showing no discernible change in the expression pattern or level in response to insulin, while in a few treated embryos a slight enhancement in the staining intensity may be present. Cells which express goosecoidparticipate in gastrulation movements and are destined to form prechordal plate eventually (Izpisüa-Belmonte et al., 1993). Elongation of body axis and enhancement of neural development in insulin treated embryos could thus appear to be independent of goosecoidexpression and do not necessarily need a corresponding increment in goosecoid transcripts.

Insulin and related molecules are known to exert mitogenic effects in avian embryonic cells (Antin et al., 1996). We therefore looked at the effects of insulin on total number of cells. We counted ethidium bromide-stained nuclei to estimate the total number of cells per blastoderm. This method gives an accurate estimate of nuclear number since yolk granules that look similar to nuclei (Fig. 2P) leading to erroneous counts can be easily distinguished from the nuclei (Fig. 2O) because of use of ethidium bromide. The estimated

\section{POSSIBLE MECHANISM OF ACTION OF INSULIN AND RELATED GROWTH FACTORS IN EARLY DEVELOPMENT}

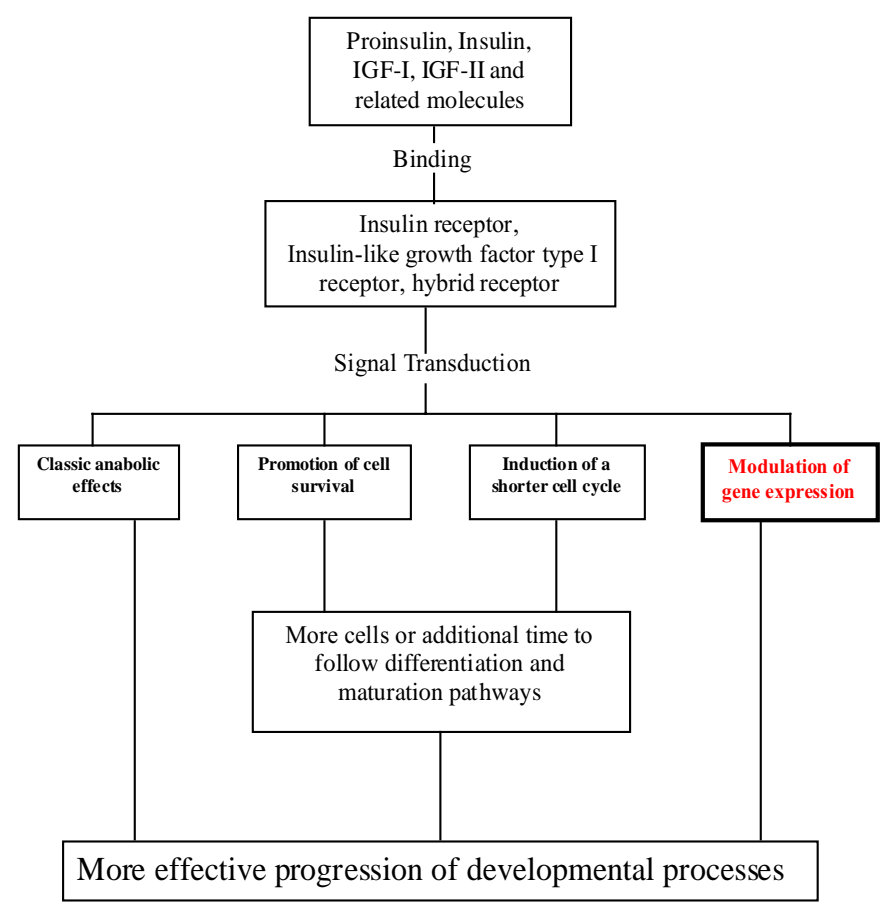

Fig. 3. Proposed pathway of development-stimulatory effect of insulin in vertebrate embryos. Transduction of signal after the binding of insulin-related ligands to receptors results in activation of multiple processes, through which overall enhancement of development is brought about. In addition to its classic anabolic effects, insulin is also known to be a mitogen and an anti-apoptotic agent in developing chick embryos, due to which there would be more cells and additional time to follow differentiation and maturation pathways. In addition to these, we propose that the insulin-induced modulation of developmental gene expression demonstrated by us, contributes significantly to the more effective progression of development in the presence of moderately elevated levels of insulin. number of cells per blastoderm in the present study agrees with published results (Ghatpande et al., 1990). A 2-h treatment with insulin that resulted in up regulation of at least three crucial genes did not exert any detectable mitogenic action in chick embryos. The results show that modulation of development-regulating genes by insulin in this system is independent of its mitogenic action, at least during the first $2 \mathrm{~h}$.

To summarize, exogenous insulin stimulates normal morphogenesis in the developing chick embryo. Importantly, stimulation of development is not only accompanied by modulation of expression of specific genes important in the regulation of morphogenesis and pattern formation but may be an outcome of it. The observed modulation of gene expression is not accompanied by increase in overall cell number. If the dose of exogenous insulin is further increased, beyond a threshold, that is different for frog and chick embryos, abnormalities are induced in the developing embryos. Thus at higher doses, insulin is teratogenic. These observations agree with the teratogenic effects of insulin documented several decades ago (Duraiswami, 1950; Landauer, 1972; Cole and Trasler, 1980).

Our studies thus demonstrate, for the first time in any developing embryonic system, modulation of expression of specific developmental genes in response to minute changes in the concentration of insulin. Based on the present and published studies carried out by others and us, we propose that a development-stimulatory effect of insulin in vertebrate embryos is brought about in the following manner (Fig. 3). Transduction of signal after the binding of insulin-related ligands to receptors results in the classic anabolic effects of insulin (reviewed by Stralfors, 1997). Insulin is also known to be a mitogen (Harvey and Kaye, 1990; Gardner and Kaye, 1991). Unprocessed proinsulin exerts an anti apoptotic effect in the developing chick embryos (Morales et al., 1997, Diaz et al., 2000). As a result of mitogenic and antiapoptotic actions of insulin, there would be more cells or additional time to follow differentiation and maturation pathways (De Pablo and Roth, 1990; De Pablo and De la Rosa, 1995). Insulin induced modulation of developmental gene expression demonstrated by us adds an altogether new dimension to the current thinking. It would appear that modulation of genes crucial for normal developmental progression also contributes significantly to the more effective progression of development in the presence of moderately elevated levels of insulin.

\section{Materials and Methods}

\section{Embryo culture, treatment and morphological observations}

Freshly laid White leghorn chicken (Gallus domesticus) eggs were incubated at $37.5^{\circ} \mathrm{C}$ to obtain the desired stages of development. The embryos were staged based on morphological criteria described by Hamburger and Hamilton (1951).

Chick embryos were explanted at Hamburger Hamilton $(\mathrm{HH})$ stage 4 and cultured by New's single ring technique (New, 1955). The embryos were treated with either bovine insulin $(0.175,1.75,17.5,87.5$ and $175 \mathrm{nM})$ or antiserum to porcine insulin (1:5000) as described before (Ghaskadbi and Mulherkar, 1984; Ghaskadbi et al., 1994). In brief, embryos were treated by carefully placing inside the ring $100 \mu$ of Pannet Compton (PC) saline (New, 1966) containing desired concentration of insulin or antiserum. The embryos were left at room temperature for $30 \mathrm{~min}$ to allow proper diffusion of the chemicals. Treated embryos along with appropriate controls (PC saline-treated cultures for insulin and preimmune rabbit serum [1:5000]- 
treated cultures for antiserum to insulin) were incubated at $37.5^{\circ} \mathrm{C}$ for the desired period. Gross morphological effects of both insulin and antiserum to insulin were studied after $22 \mathrm{~h}$ treatment while effects of insulin on embryonic gene expression were studies after $2 \mathrm{~h}$ treatment.

At the end of the $22 \mathrm{~h}$ treatment, overall development as well as development of important embryonic structures such as brain, notochord, heart, somites, etc., in control and treated embryos were recorded. The length of body axis of embryos was measured using a micrometer scale (Ghaskadbi et al., 1994). Considering the average length of the body axis of all control embryos to be $100 \%$, the extent of stimulation of growth in average treated embryo was calculated. The embryos were fixed for morphological studies.

\section{Whole mount in situ hybridization}

Chicken Brachyury (Smith et al., 1991) cDNA cloned in pBS vector was a kind gift from Prof. J. C. Smith, Cambridge, U.K. The recombinant plasmid pCBRA9 was linearized with $\mathrm{Xba} I$ and transcribed using T3 RNA polymerase in the presence of DIG labeled UTPs to get antisense transcript of 350 bases. Chicken noggin (Connolly et al., 1997) cDNA cloned in pBS vector ( $c$ Nog) was a kind gift from Dr. J. Cooke, London. Recombinant plasmid p CNog was linearized with Sacll and transcribed using T7 RNA polymerase in the presence of DIG labeled UTPs to get antisense transcript of $1.3 \mathrm{~kb}$ size. Chicken ERN/ (cERN/ 2 Sub) cDNA (Streit et al., 2000) cloned in pBS vector was a kind gift from Prof. C.D. Stern, London. Recombinant plasmid was linearized with $\mathrm{Kpnl}$ and transcribed using T3 RNA polymerase in the presence of DIG labeled UTPs to get antisense transcript of $2.1 \mathrm{~kb}$ size. Chicken goosecoid (cGsc) cDNA (Izpisüa-Belmonte et al., 1993) cloned in pBS vector was kind gift from Dr. J.C. IzpisüaBelmonte, California. Recombinant plasmid was linearized with Notl and transcribed using T3 RNA polymerase in the presence of DIG labeled UTPS to get antisense transcript of about $2 \mathrm{~kb}$ size.

Chick embryos were explanted at $\mathrm{HH}$ stage 4 and cultured in vitroin the presence of either PC saline or $17.5 \mathrm{nM}$ insulin for $2 \mathrm{~h}$ at $37.5^{\circ} \mathrm{C}$. This duration of treatment is sufficient to detect changes, if any, at the transcriptional level (Khot and Ghaskadbi, 2001; Karandikar and Ghaskadbi, 2003). The embryos were fixed in $4 \%$ paraformaldehyde at $4^{\circ} \mathrm{C}$ overnight. The embryos were thoroughly washed in PBS dehydrated in graded series of PBS: methanol and stored at $-20^{\circ} \mathrm{C}$ in $100 \%$ methanol until further use. These were processed for in situ hybridization according to the method of Nieto et al. (1996) described briefly as follows. Prior to hybridization, the embryos were rehydrated, permeabilized $(2 \mu \mathrm{g} / \mathrm{ml}$ Proteinase $\mathrm{K}$ for $20 \mathrm{~min}$ at room temperature), hybridization was carried out overnight at $58^{\circ} \mathrm{C}$ for $c B R A$ probe, $65^{\circ} \mathrm{C}$ for $c N o g$ and $c G s c$ probes and $70^{\circ} \mathrm{C}$ for $c E R N /$ probe. After blocking in $20 \%$ fetal calf serum (4을 $3 \mathrm{~h})$, embryos were incubated in 1:2000 dilution of anti-DIG antibody in the blocking solution $\left(4^{\circ} \mathrm{C}\right.$, overnight). After colour reaction with NBT/ BCIP (usually for a period between $30 \mathrm{~min}$. to a few hours, depending on the abundance of target mRNA, quality and size of the probe, amount of label incorporated, etc.) the embryos were photographed with a combination of transmitted and incident lights.

\section{Estimation of cell number}

Stage 4 chick embryos cultured using New's single ring technique were treated with $17.5 \mathrm{nM}$ insulin for $2 \mathrm{~h}$ at $37^{\circ} \mathrm{C}$. Identical numbers of stage matched embryos were allowed to develop in $100 \mu \mathrm{l}$ of PC saline. At the end of the treatment duration, embryos were homogenized and nuclear extraction was carried out as described by Ghatpande etal. (1990). Embryos were first detached from the vitelline membrane and transferred to sterile, chilled Dounce homogenizer and homogenized with a loose piston in chilled TENM $_{2}$-sucrose buffer ( $10 \mathrm{mM} \mathrm{NaCl}, 1 \mathrm{mM} \mathrm{MgCl}{ }_{2}, 1 \mathrm{mM} \mathrm{MnCl}{ }_{2}, 15 \mathrm{mM}$ triethanolamine, $\mathrm{pH} 7.6$ and $0.3 \mathrm{M}$ sucrose; McMaster and Modak, 1977). To the homogenate, ethidium bromide was added $(2 \mathrm{ng} / \mathrm{ml}$ final concentration) and stored on ice for $20 \mathrm{~min}$. Appropriately diluted homogenate was used for charging the Neubauer's chamber and fluorescent nuclei (Fig. 2O) were counted. The total number of nuclei per blastoderm was calculated.

\section{Acknowledgements}

We are grateful to Drs. Saroj Ghaskadbi and Hemant Ghate for excellent suggestions and help and to Drs. J. Cooke, J.C. IzpisüaBelmonte, Jim Smith and C.D. Stern for the clones. The work was supported by Department of Science and Technology, Government of India (Project SP/SO/D-54/96) and Intramural funds from Agharkar Research Institute, Pune (Project Zoo 9).

\section{References}

ANTIN, P.B., YATSKIEVYCH, T., DOMINGUEZ, J.L. and CHIEFFI, P. (1996). Regulation of avian precardiac mesoderm development by insulin and insulinlike growth factors. J. Cell. Physiol. 168: 42-50.

BAROFFIO, A., RODDATZ, E., MARKERT, M. and KUCERA, P. (1986). Transient stimulation of glucose metabolism by insulin in the 1-day chick embryo. J. Cell Physiol. 127: 288-297.

BASSAS, L., DE PABLO, F., LESNIAK, M.A. and ROTH, J. (1987). The insulin receptors of chick embryo show tissue-specific structural differences which parallel those of the insulin-like growth factor I receptors. Endocrinology 121: 1468-1476.

BLUMBERG, B., WRIGHT, C.V.E., DE ROBERTIS, E.M. and CHO, K.W.Y. (1991). Organizer-specific homeobox genes in Xenopus embryos. Science 253: 194196.

CHATTERJEE, S. and GHASKADBI, S. (2002). Neural abnormalities in insulindeprived frog embryos are associated with altered gene expression. Curr. SCi, 82: 92-95.

CHO, K.W.Y., BLUMBERG, B., STEINBEISSER, H. and DE ROBERTIS, E.M. (1991). Molecular nature of Spemann's organizer: the role of the Xenopus homeobox gene goosecoid. Cel/67: 1111-1120

COLE, W.A. AND TRASLER, D.G. (1980). Gene-teratogen interaction in insulin induced mouse exencephaly. Teratology22: 125-139.

CONLON, F.L. and SMITH, J.C. (1999). Interference with Brachyury function inhibits convergent extension, causes apoptosis and reveals separate requirements in the FGF and activin signalling pathways. Dev. Biol. 213: 85-100.

CONNOLLY, D.J., PATEL, K. and COOKE, J. (1997). Chick nogginis expressed in the organizer and neural plate during axial development, but offers no evidence of involvement in primary axis formation. Int. J. Dev. Biol. 41: 389-396.

DE PABLO, F. and DE LA ROSA, E. (1995). The developing CNS: a scenario for the action of proinsulin, insulin and insulin-like growth factors. Trends Neurosci. 18: $143-150$

DE PABLO, F., GIRBAU, M., GOMEZ, J.A., HERNANDEZ, E., ROTH, J. (1985). Insulin antibodies retard and insulin accelerates growth and differentiation in early embryos. Diabetes 34 , 1063-1067.

DE PABLO, F. and ROTH, J. (1990). Endocrinization of the early embryo: an emerging role for hormones and hormone-like factors. Trends Biochem. Sci. 15: 339-342.

DE PABLO, F., ROTH, J. and HERNANDEZ, E. and PRUSS, R.M. (1982). Insulin is present in chicken eggs and early chick embryos. Endocrinology 111: 19091916.

DE PABLO, F., SCOTT, L.A. and ROTH, J. (1990). Insulin and insulin-like growth factor I in early development: peptides, receptors and biological events. Endocrine Rev. 11: 558-577.

DIAZ, B., SERNA, J., DE PABLO, F. and DE LA ROSA, E.J. (2000). In vivo regulation of cell death by embryonic (pro) insulin and the insulin receptor during early retinal neurogenesis. Development 127: 1641-1649.

DURAISWAMI, P.K. (1950). Insulin induced skeletal abnormalities in developing chickens. Br. Med. J. 2: 384-390.

GARDNER, H.G. and KAYE, P.L. (1991). Insulin increases cell numbers and morphological development in mouse pre-implantation embryos in vitro. Reprod. Fertil. Dev. 3: 79-91.

GHASKADBI, S. (1998). Role of insulin during prepancreatic development of Microhyla ornata (Anura: Microhylidae). Dev. Sci. 1: 29-36.

GHASKADBI, S., ELIAS, B., PATWARDHAN, V., GARDE, S., SHETH, A.R. and GHATE, H.V. (1994). Mesoderm enhancing effect of human seminal plasma inhibin and its synthetic C-terminal nonapeptide fragment in the chick embryo. Indian J. Exp. Biol. 32: 450-457. 
GHASKADBI, S. and GHATE, H.V. (1993). Essential role of insulin during early prepancreatic development of the frog Microhyla ornata. Int. J. Dev. Biol. 37: 359-362.

GHASKADBI, S. and GHATE, H.V. (1995). Immunoneutralization of insulin modifies dorsoventral patterning in developing frog embryos. J. Biosci. 20: 473-480.

GHASKADBI, S. and MULHERKAR, L. (1984). Effects of cytochalasin H on chick embryo explants cultured in vitro. Toxicology 33: 323-330.

GHATPANDE, S.K., GUTTIKAR, G., PARANJAPE, S., MULHERKAR, L. and MODAK, S.P. (1990). Cell population growth in chick blastoderms cultivated in vitro. Indian J. Exp. Biol. 28: 526-530.

GILBERT, S.F. (2003). Developmental Biology. $7^{\text {th }}$ Edition, Sinauer Associates, Sunderland, Massachusetts.

GIRBAU, M., BASSAS, L., ALEMANY, J. and DE PABLO, F. (1989). In situ autoradiography and ligand-dependent tyrosine kinase activity reveal insulin receptors and insulin-like growth factor I receptors in prepancreatic chicken embryos. Proc. Natl. Acad. Sci. USA 86: 5868-5872.

GIRBAU, M., GOMEZ, J.A., LESNIAK, M.A. and DE PABLO, F. (1987). Insulin and insulin-like growth factor I both stimulate metabolism, growth and differentiation in the postneurula chick embryo. Endocrinology 121: 1477-1482.

GIRBAU, M., GONZÁLEZ-GUERRERO, P.R., BASSAS, L. and DE PABLO, F. (1992). Insulin receptors and insulin-like growth factor I receptors in embryos from gastrula until organogenesis. Mol. Cell. Endocrinol. 90: 69-75.

HAMBURGER, V. and HAMILTON, H.L. (1951). A study of normal stages in the development of the chick. J. Morphol. 88: 49-92.

HARVEY, M.B. and KAYE, P.L. (1990). Insulin increases the cell number of the inner cell mass and stimulates morphological development of mouse blastocysts in vitro. Development 110: 963-967.

HERRMANN, B.G., LABEIT. S., POUTSKA, A., KING, T.R. and LEHRACH, H. (1990). Cloning of the $T$ gene required in mesoderm formation in the mouse. Nature 343: 617-622.

HIRSINGER, E., DUPREZ, D., JOUVE, C., MALAPERT, P., COOKE, J. and POURQUIE, O. (1997). Noggin acts downstream of Wnt and Sonic Hedgehog to antagonize BMP4 in avian somite patterning. Development 124: 4605-4614.

IZPISüA-BELMONTE, J.C., DE ROBERTIS, E.M., STOREY, K.G. and STERN, C. (1993). The homeobox gene goosecoid and the origin of organizer cells in the early chick blastoderm. Cel/74: 645-659.

KARANDIKAR, S. and GHASKADBI, S. (2003). $\beta$-Microseminoprotein-related molecules may participate in formation of the mesoderm in the chick embryo. Dev. Growth Differ. 45: 309-319.

KHOT, S. and GHASKADBI, S. (2001). FGF signaling is essential for the early events in the development of the chick nervous system and mesoderm. Int. J. Dev. Biol. 45: 877-885.

KISPERT, A., ORTNER, H., COOKE, J. and HERRMANN, B.G. (1995). The chick brachyury gene: developmental expression pattern and response to axial induction by localized activin. Dev. Biol. 168: 406-415.

LANDAUER, W. (1972). Is insulin a teratogen? Teratology 5: 129-135.

McMASTER, G. and MODAK, S.P. (1977). Cellular and biochemical parameters of growth of chick blastoderm during early morphogenesis. Differentiation, 8:145152.
MORALES, A.V., SERNA, J., ALARCÓN, C., DE LA ROSA, E.J. and DE PABLO, F. (1997). Role of prepancreatic (pro) insulin and the insulin receptor in prevention of embryonic apoptosis. Endocrinology 138: 3967-3875.

NEW, D.A.T. (1955). A new technique for the cultivation of chick embryo in vitro. J. Embryol. Exp. Morpho/3: 326-331.

NEW, D.A.T. (1966) The culture of vertebrate embryos. Logos Press, London.

NIEHRS, C., KELLER, R., C.H.O., K.W.Y. and DE ROBERTIS, E.M. (1993). The homeobox gene goosecoidcontrols cell migration in Xenopusembryos. Cel/72: 491-503.

NIETO, M.A., PATEL, K. and WILKINSON, D.G. (1996). In situ hybridization analysis of chick embryos in whole mount and tissue sections. Meth. Cell Biol. 51: 219-235.

PATWARDHAN, V. and GHASKADBI, S. (2001). Activin disrupts somitogenesis in cultured chick embryos. Dev. Genes Evol. 211: 478-485.

PÉREZ-VILLAMIL, B., DE LA ROSA, E.J., MORALES, A.V. and DE PABLO, F. (1994). Developmentally regulated expression of the preproinsulin gene in the chicken embryo during gastrulation and neurulation. Endocrinology 135: 23422350.

PICCOLO, S., SASAI, Y., LU, B. and DE ROBERTIS, E.M. (1996). Dorsoventral patterning in Xenopus: inhibitions of ventral signals by direct binding of chordin to BMP-4. Cel/86: 589-598.

SMITH, J.C. (1997). Brachyury and the T-box genes. Curr. Opin. Genet. Dev. 7: 474-480.

SMITH, J.C. (2001). Making mesoderm -upstream and downstream of Xbra. Int. J. Dev. Biol. 45: 219-224.

SMITH, J.C., PRICE, B.M., GREEN, J.B., WEIGEL, D. and HERRMANN, B.G. (1991). Expression of a Xenopus homolog of Brachyury (T) is an immediateearly response to mesoderm induction. Cel/67: 79-87.

SMITH, W.C. and HARLAND, R.M. (1992) Expression cloning of noggin, a new dorsalizing factor localized to the Spemann organizer in Xenopusembryos. Cell 70: $829-840$.

STRALFORS, P. (1997). Insulin second messengers. BioEssays 19: 327-335.

STREIT, A., BERLINER, A.J., PAPANAYOTOU, C., SIRULNIK, A. and STERN, C.D. (2000). Initiation of neural induction by FGF signalling before gastrulation. Nature 406: 74-78.

STREIT, A. and STERN, C.D. (1999). Mesoderm patterning and somite formation during node regression: differential effects of chording and noggin. Mech. Dev. 85: 85-96.

WILSON, V. and BEDDINGTON, R. (1997). Expression of T protein in the primitive streak is necessary and sufficient for posterior mesoderm movement and somite differentiation. Dev. Biol. 192: 45-58.

ZIMMERMAN, L.B., DE JESUS-ESCOBAR, J.M. and HARLAND, R.M. (1996). The Spemann organizer signal noggin binds and inactivates bone morphogenetic protein 4. Cel/86: 599-606.

Received: March 2004

Reviewed by Referees: April 2004

Modified by Authors and Accepted for Publication: May 2004

Edited by: Makoto Asashima 